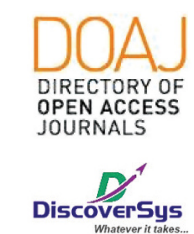

Published by DiscoverSys

\section{Diagnosis dan tatalaksana Sindroma Stevens-Johnson (SJS) pada anak: tinjauan pustaka}

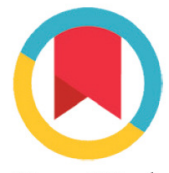

CrossMark

\author{
Komang Ayu Witarini
}

\section{ABSTRACT}

Background: Stevens-Johnson Syndrome (SJS) is an emergency situation with a fairly high mortality rate characterized by a triad of lesions on the skin, mucosa orifice, and eyes. In general, SJS is caused by a reaction to a drug. This literature review is trying to explain more in the effort to diagnose and manage SJS specifically in children.

Methods: This literature review involved 14 relevant literature from 1990-2011 about SJS. Different data sources or manual literature search methods used to find articles related to the topic of literature.

Results: The diagnosis of SJS is mainly based on clinical symptoms. The clinical picture of SJS is known to be very similar to Toxic Epidermolysis Necrotikans (TEN). Various efforts to stop all drugs given previously is the main treatment, supported by supportive treatment of accompanying symptoms. The mortality rate depends on the presence of severe complications and delay of treatment.

Conclusion: Early diagnosis and prompt treatment are the key to the management of SJS in children.

Keywords: Stevens-Johnson syndrome, diagnosis, management, children

Cite This Article: Witari, K.A. 2019. Diagnosis dan tatalaksana Sindroma Stevens-Johnson (SJS) pada anak: tinjauan pustaka. Intisari Sains Medis 10 (3): 592-596. DOl: 10.15562/ism.v10i3.588

Departemen/KSM IImu Kesehatan Anak Fakultas Kedokteran Universitas Udayana/RSPTN Universitas Udayana, Bali, Indonesia
Korespondensi: Komang Ayu Witarini; Departemen/KSM IImu Kesehatan Anak Fakultas Kedokteran Universitas Udayana/ RSPTN Universitas Udayana, Bali, Indonesia; ayuwitarini@gmail.com

Diterima: 15-08-2019 Disetujui: 03-09-2019 Diterbitkan: 01-12-2019

\title{
ABSTRAK
}

Latar Belakang: Sindroma Stevens-Johnson (SJS) merupakan keadaan gawat darurat dengan angka kematian cukup tinggi yang ditandai dengan trias lesi pada kulit, mukosa orifisium, dan mata. Pada umumnya disebabkan oleh reaksi terhadap obat. Tinjauan kepustakaan ini berusaha untuk memaparkan lebih dalam upaya diagnosis dan tatalaksana SJS khusus pada anak.

Metode: Tinjauan kepustakaan ini melibatkan 14 literatur yang relevan dari tahun 1990-2011 tentang SJS. Sumber data yang berbeda maupun metode pencarian literatur secara manual dipergunakan untuk menemukan artikel yang berhubungan dengan topik kepustakaan.

Hasil: Diagnosis SJS terutama dilakukan berdasarkan pada gejala klinis. Gambaran klinis SJS diketahui sangat mirip dengan Toxic Epidermolysis Necrotikans (TEN). Upaya penghentian semua obat yang diberikan sebelumnya merupakan tatalaksana utama, didukung oleh pengobatan suportif terhadap gejala penyerta. Angka kematian tergantung pada adanya komplikasi yang berat dan keterlambatan pengobatan.

Kesimpulan: Diagnosis dini maupun tatalaksana yang tepat merupakan kunci terhadap penanganan SJS pada anak.

Kata Kunci: Sindroma Stevens-Johnson, diagnosis, tatalaksana, anak

Site Pasal ini: Witari, K.A. 2019. Diagnosis dan tatalaksana Sindroma Stevens-Johnson (SJS) pada anak: tinjauan pustaka. Intisari Sains Medis 10 (3): 592-596. D0l: 10.15562/ism.v10i3.588

\section{PENDAHULUAN}

Sindroma Stevens-Johnson (SSJ) merupakan kumpulan gejala klinis yang ditandai oleh trias kelainan pada kulit, mukosa orifisium (oral, konjungtiva dan anogenital), serta mata disertai oleh gejala umum yang berat. SSJ pertama kali dikenal menurut deskripsi Stevens dan Johnson tahun 1922. ${ }^{1}$ Penyakit ini mempunyai banyak sinonim, diantaranya sindrom de Friessinger-Rendu, eritema poliform bulosa, sindrom muko-kutaneo-okular, dan dermatostomatitis. Istilah eritema multiform sering dipakai untuk menggambarkan SSJ karena merujuk pada kelainan kulit yang dijumpai. Namun studi klinis terbaru telah membuktikan bahwa istilah eritema multiform tidak dapat digunakan untuk menggambarkan SSJ karena kedua penyakit ini berbeda. ${ }^{1-3}$ 
Kejadian SSJ jarang dijumpai pada anak dan lebih sering pada usia dewasa, dengan angka insiden 1-7 per sejuta anak setiap tahun..$^{4-6}$ SJS memiliki angka mortalitas yang tinggi yaitu mencapai $25 \%-70 \%$, dan tingkat mortalitas tertinggi ditemukan terjadi pada usia tua., ${ }^{4,5}$ Tingkat mortalitas pada usia anak ditemukan lebih rendah daripada usia tua, namun setengah dari anak-anak yang terkena penyakit SJS menderita komplikasi jangka Panjang. ${ }^{4}$ Walaupun jarang, SSJ merupakan bentuk kegawatdaruratan dengan angka kematian dan kejadian kecacatan yang cukup tinggi. Pada kasus sedang sampai berat didapatkan angka kematian sebesar 5-15\%.5,7,8 Gejala sisa paling sering dijumpai pada kulit dan mata. $^{5}$

Dewasa ini, etiologi dari SJS juga masih belum dapat dijelaskan dengan pasti dikarenakan SJS dapat disebabkan oleh berbagai faktor, namun pada umumnya penyakit ini timbul karena reaksi alergi tubuh terhadap obat yang dikonsumsi. Sebagian besar kejadian kematian dan timbulnya kecacatan disebabkan oleh tata laksana yang tidak optimal akibat terlambatnya pengenalan SSJ. Sehingga sangat penting bagi tenaga kesehatan untuk memiliki kemampuan dalam mendiagnosis dan melakukan tatalaksana SSJ yang optimal agar angka kematian dan kejadian kecacatan dapat diturunkan.

Berkaitan dengan pemaparan latar belakang tersebut maka studi tinjauan pustaka ini bertujuan untuk menjelaskan lebih dalam upaya diagnosis maupun penatalaksanaan terkini terhadap kasus SJS yang terjadi pada anak dimana dimulai dengan pemaparan terhadap etiologi penyakit, patogenesis, manifestasi klinis, penegakan diagnosis, diagnosis banding, penatalaksanaan, komplikasi, hingga prognosis SJS pada anak pasca terapi.

\section{ETIOLOGI}

Penyebab pasti seringkali sukar ditentukan oleh karena SSJ dapat disebabkan oleh berbagai faktor. Beberapa faktor penyebab diantaranya infeksi (virus [herpes simplex, mycoplasma pneumonia, vaksinia], jamur [koksidioidomikosis, histoplasma], bakteri [streptokokus, Staphylococcus haemolyticus, Mycobacterium tuberculosis, salmonela], dan parasit [malaria]), makanan (coklat), obat (salisilat, sulfa, penisilin, etambutol, tegretol, tetrasiklin, digitalis, kontraseptif, klorpromazin, karbamazepin, kinin, oxicam-NSAID, dan asetaminofen [parasetamol]), penyakit kolagen, keganasan, kehamilan, dan vaksinasi. ${ }^{7}$ Faktor fisik (udara dingin, sinar matahari, sinar X) berperan sebagai pencetus. ${ }^{8,9}$

Sebagian besar kasus SSJ (74\%-94\% kasus) berkaitan dengan respon imun terhadap obat. ${ }^{7-}$

${ }^{9}$ Obat tersering dilaporkan sebagai penyebab adalah golongan salisilat, sulfonamid, penisilin,
oxicam-NSAID, antiepilepsi, nevirapine, dan allopurinol. ${ }^{10-12}$ Keterlibatan kausal ditujukan terhadap obat yang diberikan sebelum masa awitan gejala klinis yang dicurigai (dapat sampai 21 hari). Bila obat yang diberikan lebih dari satu macam maka semua obat tersebut harus dicurigai mempunyai hubungan kausal.

\section{PATOGENESIS SJS}

Patogenesis SSJ sampai saat ini masih belum jelas walaupun sering dihubungkan dengan reaksi hipersensitivitas tipe III dan IV. Pada beberapa kasus yang dilakukan biopsi kulit dapat ditemukan endapan IgM, IgA, C3 dan fibrin, serta circulating immune complex dalam sirkulasi. ${ }^{7,8}$

Antigen penyebab berupa hapten akan berikatan dengan karier yang dapat merangsang respon imun spesifik sehingga terbentuk kompleks imun beredar. Hapten atau karier tersebut dapat berupa faktor penyebab (misalnya virus, partikel obat atau metabolitnya) atau produk yang timbul akibat aktivitas faktor penyebab tersebut (struktur sel atau jaringan sel yang rusak dan terbebas akibat infeksi, inflamasi atau proses metabolik). ${ }^{8}$ Circulating immune complex (CIM) dapat mengendap di daerah kulit dan mukosa, serta menimbulkan kerusaan jaringan akibat aktivasi komplemen dan reaksi inflamasi yang terjadi. Kerusakan jaringan dapat pula terjadi akibat aktivitas sel $\mathrm{T}$ serta mediator yang dihasilkannya. Kerusakan jaringan yang terlihat sebagai kelainan klinis lokal di kulit dan mukosa dapat pula disertai gejala sistemik akibat aktivitas mediator serta produk inflamasi lainnya. Adanya reaksi imun sitotoksik juga mengakibatkan apoptosis keratinosit yang akhirnya menyebabkan kerusakan epidermis. ${ }^{7-9}$ Kerusakan epidermis membawa beberapa implikasi, yaitu kegagalan fungsi kulit yang menyebabkan terjadinya kehilangan cairan tubuh, kegagalan termoregulasi, dan meningkatkan risiko infeksi.

\section{MANIFESTASI KLINIS}

Gejala prodromal terjadi dalam 1-14 hari dan sangat bervariasi dalam derajat berat serta kombinasi gejala. Gejala prodromal dapat berupa demam, malaise, batuk, koriza, sakit menelan, sakit kepala, nyeri dada, muntah, myalgia, dan atralgia. Setelah itu akan timbul lesi kulit, mukosa, dan mata. ${ }^{8,12}$

Lesi pada kulit bersifat simetris, dapat berupa eritema, papel, vesikel, atau bula. Lesi spesifik berupa lesi target timbul akibat adanya perdarahan pada lesi yang menimbulkan gejala fokal berbentuk target, iris, atau mata sapi..$^{10-12}$ Pada keadaan lanjut dapat terjadi erosi, ulserasi, kulit mengelupas (tanda Nikolsky positif) dan pada kasus berat pengelupasan 
kulit dapat terjadi pada seluruh tubuh disertai paronikia dan pengelupasan kuku. Predileksi lesi adalah pada area muka, ekstensor tangan dan kaki, serta dapat meluas ke seluruh tubuh. Jumlah dan luas lesi meningkat dan mencapai puncaknya pada hari keempat sampai kelima. ${ }^{12}$

Lesi pada mukosa dapat terjadi bersamaan atau bahkan mendahului timbulnya lesi di kulit. Pada mukosa mulut, tenggorokan, dan genital dapat ditemukan vesikel, bula, erosi, ekskoriasi, perdarahan, dan krusta berwarna merah. Pada faring dapat terbentuk pseudomembran berwarna putih atau keabuan yang menimbulkan kesukaran menelan. Pada bibir dapat dijumpai krusta kehitaman yang disertai stomatitis berat pada mukosa mulut. Lesi jarang terjadi pada mukosa hidung dan anus, tetapi pada kasus berat dapat terjadi lesi yang luas sampai ke daerah trakeobronkial. ${ }^{12}$

Kelainan mata berupa konjungtifitis kataralis, blefarokonjungvitis, iritis, iridosiklitis, pembentukan pseudomembran, kelopak mata edema dan sulit dibuka, sekret mata purulen disertai dengan fotofobia. Pada kasus berat dapat terjadi erosi dan perforasi kornea. ${ }^{12}$

Gejala klinis SSJ biasanya timbul cepat dengan keadaan umum yang berat, disertai demam, dehidrasi, gangguan pernafasan, muntah, diare, melena, pembesaran kelenjar getah bening, hepatosplenomegali, sampai pada penurunan kesadaran dan kejang. ${ }^{10,11}$ Perjalanan penyakit dapat berlangsung beberapa hari sampai 6 minggu, tergantung dari derajat berat penyakitnya.

\section{PENEGAKAN DIAGNOSIS}

Diagnosis SSJ 90\% dibuat berdasarkan gambaran klinis, yaitu didapatkannya trias kelainan pada kulit, mukosa, dan mata. ${ }^{1}$ Anamnesis ditujukan untuk mengetahui faktor penyebab, dimana faktor penyebab tersering adalah obat. ${ }^{7-}$

9 Pemeriksaan laboratorium ditujukan untuk mencari hubungan dengan faktor penyebab serta untuk penatalaksanaan secara umum. Pemeriksaan laboratorium antara lain pemeriksaan darah tepi, pemeriksaan imunologis, biakan kuman dan uji resistensi dari darah dan tempat lesi serta pemeriksaan histopatologi biopsi kulit. ${ }^{11}$

Anemia dapat dijumpai pada kasus berat dengan perdarahan, leukosit biasanya normal atau sedikit meninggi, terdapat peningkatan eosinofil. Kadar IgG dan IgM dapat meninggi, C3 dan C4 normal atau sedikit menurun dan dapat dideteksi adanya circulating immune complex. ${ }^{12}$ Pada pemeriksaan histopatologi dapat ditemukan gambaran nekrosis di epidermis sebagian atau menyeluruh, edema intrasel di daerah epidermis, pembengkakan endotel, serta eritrosit yang keluar dari pembuluh darah dermis superfisial. Pemeriksaan imunofluoresen dapat memperlihatkan endapan IgM, IgA, C3 dan fibrin. ${ }^{12,13}$

\section{DIAGNOSIS BANDING}

Ada 3 penyakit yang sangat mirip dengan SSJ, yaitu Toxic Epidermolysis Necrotikans (TEN), eritema multiform (EM) dan Staphylococcal Scalded Skin Syndrome (SSSS). TEN dibedakan dengan SSJ berdasarkan luas lesi pada kulit. ${ }^{12}$ TEN apabila luas lesi $>30 \%$ permukaan tubuh, SSJ bila luas lesi $<10 \%$ luas permukaan tubuh dan bila luas lesi 10$30 \%$ luas permukaan tubuh didefinisikan sebagai SSJ/TEN. EM dan SSJ sering dianggap sama oleh karena pada kedua penyakit tersebut didapatkan lesi dengan predileksi yang sama, yaitu pada kulit dan mukosa oral. ${ }^{12,13}$ Perbedaan EM dengan SSJ dapat dilihat mulai dari faktor penyebab. Infeksi herpes simpleks merupakan penyebab tersering EM, berbeda dengan SSJ yang lebih sering disebabkan oleh obat. Secara klinis, target lesi pada EM sangat khas karena terbagi menjadi tiga lapisan dimana gambaran ini tidak ditemukan pada SSJ. Lesi mukosa pada EM didapatkan terbatas hanya pada mukosa oral, sedangkan pada SSJ lesi dapat ditemukan juga pada mukosa konjungtiva dan anogenital. Perbedaan SSJ dengan SSSS, yaitu pada lesi kulit dimana SSSS ditandai dengan krusta yang mengelupas pada seluruh kulit dan biasanya mukosa tidak terkena. ${ }^{12,13}$

\section{PENATALAKSANAAN}

Keberhasilan penanganan SSJ sangat ditentukan oleh pengenalan gejala secara dini, menghentikan atau mengatasi faktor penyebab dan pemberian terapi suportif yang adekuat. Deteksi faktor penyebab yang paling umum yaitu penggunaan obat sebelumnya dan penghentiannya segera, telah terbukti dapat menurunkan angka mortalitas dan memperbaiki prognosis., ${ }^{9,12}$

Terapi suportif merupakan tata laksana yang penting pada pasien SSJ. ${ }^{13}$ Pasien yang umumnya datang dengan keadaan umum berat membutuhkan cairan dan elektrolit, serta kebutuhan kalori dan protein yang sesuai secara parenteral. Pemberian cairan tergantung dari luasnya kelainan kulit dan mukosa yang terlibat. Pemberian nutrisi melalui pipa nasogastrik dilakukan sampai mukosa oral kembali normal. Perawatan yang baik terhadap lesi pada kulit akan mengurangi kemungkinan infeksi dan rasa nyeri. ${ }^{13}$ Blister pada kulit dapat dikompres dengan larutan salin atau borowi. Hindari penggunaan salep kulit yang mengandung sulfa. Lesi kulit yang terbuka dirawat seperti luka bakar, 


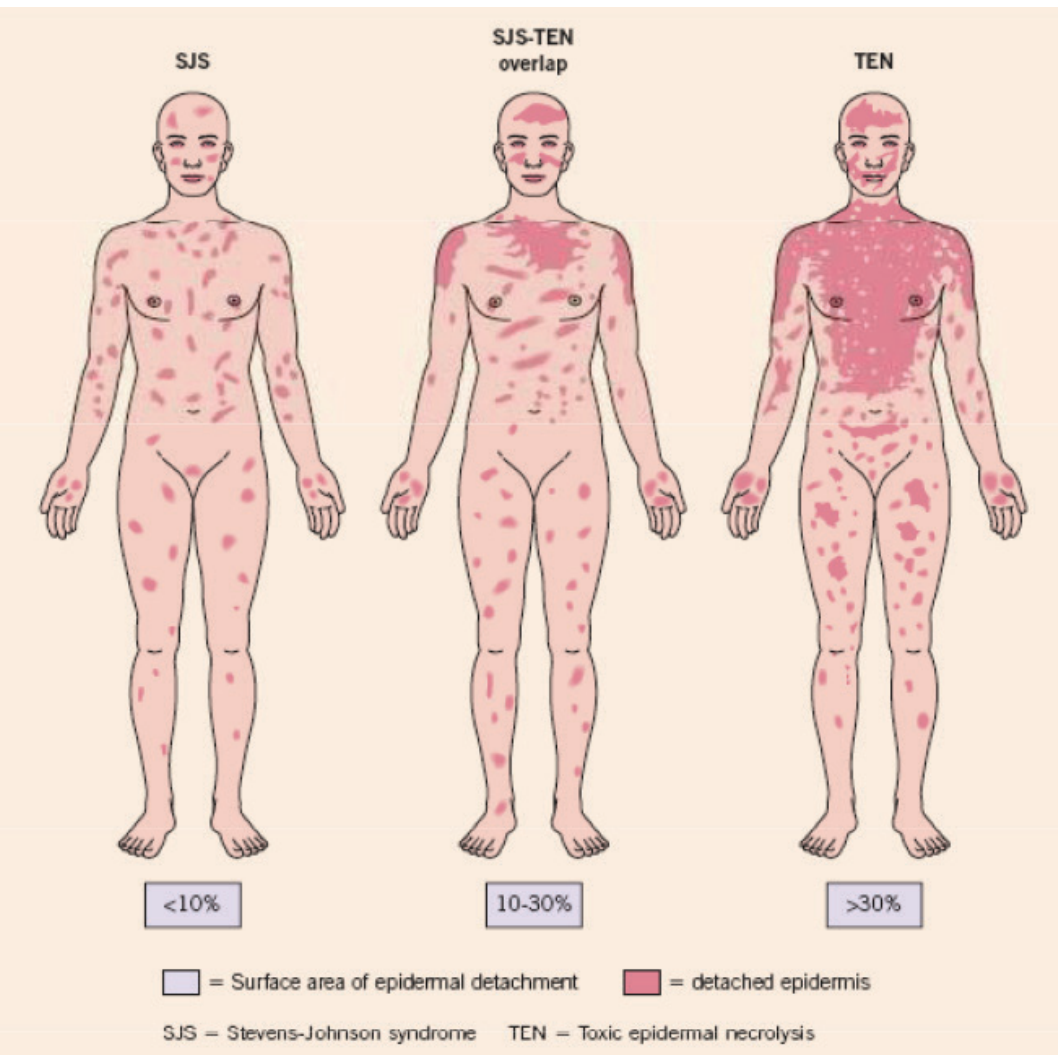

Gambar 1. Perbedaan SSJ, SSJ-TEN overlap, dan TEN berdasarkan luas lesi pada kulit dan mukosa. ${ }^{3}$

sehingga koordinasi dengan unit luka bakar sangat diperlukan. Lesi di mukosa mulut diberikan obat pencuci mulut dan salep gliserin. Pengendalian rasa nyeri dengan oxicam-NSAIDs sebaiknya tidak diberikan mengingat merupakan salah satu obat yang telah terbukti sering sebagai faktor penyebab SSJ..$^{13}$

Pengobatan infeksi sekunder pada kulit, sebagai terapi awal dapat diberikan antibiotik spektrum luas, dapat digunakan gentamisin $5 \mathrm{mg} / \mathrm{kgBB} /$ hari intramuskuler. Pemberian antibiotika selanjutnya berdasarkan hasil biakan dan uji resistensi kuman dari sediaan lesi kulit dan darah. Pemilihan antibiotika sebaiknya tidak menggunakan golongan sulfa dan penisilin yang memiliki resiko tinggi untuk terjadinya SSJ. ${ }^{13}$

Pemberian kotikosteroid sistemik sebagai terapi SSJmasihkontroversial.Beberapapenelitimenyetujui pemberian kortikosteroid sistemik beralasan bahwa kortikosteroid akan menurunkan beratnya penyakit, mempercepat konvalesensi, mencegah komplikasi berat, menghentikan progresifitas penyakit dan mencegah kekambuhan. ${ }^{12,13}$ Beberapa literatur menyatakan pemberian kortikosteroid sistemik dapat mengurangi inflamasi dengan cara memperbaiki integritas kapiler, memacu sintesa lipokortin, menekan ekspresi molekul adesi. Selain itu kortikosteroid dapat meregulasi respons imun melalui down regulation ekspresi gen sitokin. Mereka yang tidak setuju pemberian kortikosteroid berargumentasi bahwa kortikosteroid akan menghambat penyembuhan luka, meningkatkan resiko infeksi, menutupi tanda awal sepsis, perdarahan gastro-intestinal dan meningkatkan mortalitas. Faktor lain yang harus dipertimbangkan yaitu harus tappering off 1-3 minggu. Bila tidak ada perbaikan dalam 3-5 hari, maka sebaiknya pemberian kortikosteroid dihentikan. ${ }^{12,13}$

Penggunaan Human Intravenous Immunoglobulin (IVIG) pada SSJ juga masih kontroversi. Beberapa studi klinis berpendapat bahwa pemberian IVIG dengan dosis 1 gr/ $\mathrm{kgBB} /$ hari selama tiga hari berturut-turut dapat menurunkan progresivitas penyakit SSJ. Pemberian IVIG akan menghambat reseptor FAS dalam proses kematian keratinosit yang dimediasi FAS. ${ }^{13,14}$

Konsultasi dilakukan kepada bagian oftalmologi untuk kelainan pada mata. Untuk mencegah sekuele pada mata dapat diberikan airmata artifisial, atau gentamisin tetes mata bila ada dugaan infeksi sekunder. Secara rutin pasien SSJ juga dikonsulkan ke bagian kulit dan kelamin untuk perawatan yang komprehensif. Konsultasi kepada bagian bedah plastik dilakukan sehubungan dengan perawatan lesi kulit terbuka yang biasanya dirawat sebagaimana luka bakar. ${ }^{13}$

\section{KOMPLIKASI}

SSJ sering menimbulkan komplikasi pada mata, diantaranya ulkus kornea dan simblefaron. Komplikasi lain yang dapat terjadi adalah gangguan keseimbangan cairan dan elektrolit, bronkopneumonia, nefritis, miositis, mielitis, poliartritis serta yang terberat adalah septikemia. ${ }^{12,13}$

\section{PROGNOSIS}

Pada kasus yang tidak berat prosnosisnya baik dan penyembuhan terjadi dalam waktu 2-3 minggu. Pada kasus berat dengan berbagai komplikasi atau dengan pengobatan terlambat dan tidak adekuat, angka kematian berkisar antara 5-15\%. Adanya sekuele seperti gangguan pernafasan, gagal ginjal, dan kebutaan juga memperburuk prognosis. ${ }^{12,13}$ Kematian dapat disebabkan oleh gangguan keseimbangan cairan dan elektrolit, bronkopneumonia, serta septikemia.

\section{KESIMPULAN}

SSJ merupakan keadaan gawat darurat dengan angka kematian yang cukup tinggi. Pada umumnya disebabkan oleh reaksi terhadap obat, walaupun 
faktor penyebab infeksi harus juga dipikirkan. Diagnosis ditegakkan berdasarkan adanya trias kelainan pada kulit, mukosa dan mata. Keberhasilan penanganan SSJ sangat ditentukan oleh kemampuan pengenalan gejala secara dini, penghentian dan mengatasi faktor penyebab segera serta pemberian terapi suportif yang adekuat. Pada kasus yang tidak berat prognosisnya cukup baik, namun harus diwaspadai adanya komplikasi yang dapat memperburuk prognosis.

\section{KONFLIK KEPENTINGAN}

Tidak terdapat konflik kepentingan dalam penulisan tinjauan kepustakaan ini

\section{PENDANAAN}

Tidak ada

\section{Kontribusi Penulis}

Penulis berkontribusi secara penuh dalam pencarian literatur yang relevan hingga penyusunan artikel ini secara komprehensif

\section{DAFTAR PUSTAKA}

1. Harr T, French LE. Toxic epidermal necrolysis and stevensjohnson syndrome. Orphanet J Rare Dis. 2010;5:39-50.

2. Léauté-Labrèze $\mathrm{C}$, Lamireau $\mathrm{T}$, Chawki $\mathrm{D}$, Maleville $\mathrm{J}$, Taieb A. Diagnosis, classification, and management of erythema multiforme and Stevens-Johnson syndrome. Arch Dis Child. 2000;83(4):347-52.

3. Bastuji-Garin S, Rzany B, Stem RS, Shear NH, Naldi L, Roujeau JC. Clinical classification of cases of toxic epidermal necrolysis, Stevens-Johnson syndrome and erythema multiforme. Arch Dermatol. 1993;129(1):92-6.

4. Gerull R, Nelle M, Schaible T. Toxic epidermal necrolysis and Stevens-Johnson syndrome: a review. Crit Care Med. 2011;39(6):1521-32

5. Finkelstein Y, Soon GS, Acuna P, George M, Pope E, Ito $S$, et al. Recurrence and outcomes of Stevens-Johnson syndrome and toxic epidermal necrolysis in children. Pediatrics. 2011;128(4):723-8.

6. Chan HL, Stern RS, Arndt KA, Langlois J, Jick SS, Jick $\mathrm{H}$, et al. The incidence of erythema multiforme, StevensJohnson syndrome, and toxic epidermal necrolysis: a population-based study with particular reference to reactions caused by drugs among outpatients. Arch Dermatol. 1990;126(1):43-7.

7. Levi N, Bastuji-Garin S, Mockenhaupt M, Roujeau JC, Flahault A, Kelly JP, et al. Medications as risk factors of Stevens-Johnson syndrome and toxic epidermal necrolysis in children: a pooled analysis. Pediatrics. 2009;123(2) e:297-304.

8. Roujeau JC, Kelly JP, Naldi L, Rzany B, Stern RS, Anderson $\mathrm{T}$, et al. Medication use and the risk of Stevens-Johnson syndrome or toxic epidermal necrolysis. N Engl J Med. 1995;333(24):1600-7.

9. Singalavanija S, Limpongsanurak W. Stevens-Johnson syndrome in Thai children: a 29-year study. J Med Assoc Thai. 2011;94 suppl 3:S85-90.

10. Auquier-Dunant A, Mockenhaupt M, Naldi I, Correia O, Schroder W, Roujeau JC. Correlations between clinical pattern and causes of erythema multiforme majus, Stevens-Johnson syndrome, and toxic epidermal necrolysis: results of an international prospective study. Arch Dermatol. 2002;138(8):1019-24.

11. Coopman SA, Stern RS. Cutaneous drug reactions in human immunodeficiency virus infection. Arch Dermatol. 1991;127(5):714-7.

12. Morelli JG. Vesiculobullous Disorders. In: Behrman RE, Kliegman RM, Jenson HB Stanton BF, editors. Nelson textbook of pediatrics. 18th Ed. Philadelphia: WB Saunders; 2007;2685-93.

13. Khalili B, Bahna SL. Pathogenesis and recent therapeutic trends in Stevens-Johnson syndrome and toxic epidermal necrolysis. Ann Allergy Asthma Immunol. 2006;97(3):27280.

14. Metry DW, Jung P, Levy ML. Use of intravenous immunoglobulin in children with stevens-johnson syndrome and toxic epidermal necrolysis: seven cases and review of the literature. Pediatrics. 2003;112(6 Pt 1):14306.

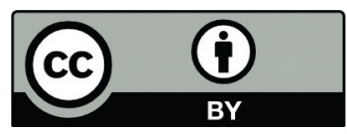

This work is licensed under a Creative Commons Attribution 